\title{
Statyba
}

\section{FACILITIES MANAGEMENT MULTIPLE CRITERIA ANALYSIS}

\section{E. K. Zavadskas , A. Kaklauskas , N. Lepkova \& J. Zalatorius}

To cite this article: E. K. Zavadskas , A. Kaklauskas , N. Lepkova \& J. Zalatorius (2001) FACILITIES MANAGEMENT MULTIPLE CRITERIA ANALYSIS, Statyba, 7:6, 481-489, DOI: 10.1080/13921525.2001.10531776

To link to this article: https://doi.org/10.1080/13921525.2001.10531776

曲 Published online: 30 Jul 2012.

Submit your article to this journal $\pi$

LIII Article views: 281

4 Citing articles: 3 View citing articles 진 


\title{
PASTATU ŪKIO VALDYMO DAUGIAKRITERINE் ANALIŻ
}

\author{
E. K. Zavadskas, A. Kaklauskas, N. Lepkova, J. Zalatorius \\ Vilniaus Gedimino technikos universitetas
}

\section{Pastaty ūkio valdymo apibrèžimų analizè}

Pastatu ūkio valdymo objektą ivairių šalių mokslininkai dažnai supranta nevienodai. Pavyzdžiui, Vokietijos mokslininku [1] nuomone, „pastatu ūkio valdymo objektą sudaro aplinka, infrastruktūra, pastatai, jame esantys irenginiai, iranga, baldai. Pagrindinis pastaty ūkio valdymo (PŪV) tikslas yra teikti užsakovui reikalingu paslaugu kompleksą, apimantị racionaly veiklos pastatuose planavimą ir igyvendinimą, pritaikymą prie besikeičiančių poreikiu, siekiant sudaryti geras sąlygas efektyviai organizacijos veiklai plètoti“. Dèl to padidèja ir nekilnojamojo turto vertè. Sis požiūris nenustato griežtu ribu tarp pastatụ ūkio valdymo ir nekilnojamojo turto valdymo objektu ir ju funkciju. Olandijoje [2] manoma, kad ,pagrindinis pastatu ūkio vadybininko tikslas, padedantis užtikrinti efektyvią organizacijos veikla, yra nustatyti reikalingu paslaugu kompleksą, kokybę, apimtị ir jas teikti sutartu laiku ir už sutartą kainą". Tuo tarpu nekilnojamojo turto vadybininkas siekia gauti pelną iš eksploatuojamo pastato.

Peterio Barretto nuomone [3], PŪV orientuotas $\mathfrak{i}$ naudojamus pastatus: planuoti, projektuoti ir valdyti užimtus pastatus ir su jais susijusias sistemas, irenginius ir baldus, siekiant užtikrinti ir (galbūt) padidinti organizacijos galimybes siekiant numatytu tikslu. PŪV padeda didinti organizacijos veiklos efektyvumą. PŪV tai procesas, kuris padeda organizacijai užsitikrinti, kad jos pastatai, sistemos ir kitos paslaugos efektyviai palaikytu pagrindinę organizacijos veiklą ir padètu pasiekti numatytus strateginius tikslus [4].

Wes McGregor ir Danny Shiem-Shim Then [5] pastatų ūkio valdymą apibūdina kaip ,infrastruktūrą, kuri teikia paramą žmonèms organizacijoje, besistengiantiems pasiekti organizacijos iškeltus tikslus“. Kitais žodžiais tariant, PŪV - tai priemonès, kurias gali taikyti žmonès, norintys atlikti tam tikras užduotis.
Jungtinių Valstijų Kongreso biblioteka [6] pateikè apibrèžimą, kuriuo dažnai remiamasi aiškinant PŪV sferą: „Praktinis fizinès darbo vietos derinimas su žmoniu poreikiais ir jų veikla organizacijoje; ši sfera jungia tokių mokslụ, kaip veiklos administravimas, architektūra ir inžinerijos principus".

Iš Tarptautinès pastatu ūkio valdymo asociacijos pateikto apibrežimo [7] matyti, kad pagrindinè PŪV veikla yra neatskiriamai susijusi su organizacijos pastatu aptarnavimu ir valdymu, su paramos teikimu produktyviai darbo aplinkai kurti.

Pastatu ūkio valdymo institutas Didžiojoje Britanijoje [5] akcentuoja daugiareikšmi pastatų ūkio vadybininkụ vaidmenị. Jo pateikiamame apibrěžime siejama atsakomybė už aptarnavima, priežiūrą ir plètotès paslaugas pradedant nekilnojamojo turto strategija, valdymu ir komunikaciju infrastruktūra, baigiant pastato priežiūra, administravimu ir sandoriu valdymu. Efektyvus PŪV svarbus sèkmingai organizacijos veiklai užtikrinti.

F. Beckerio [8] siūlomas PŪV apibrèžimas yra toks: „PŪV terminas apima planavimo, projektavimo ir kompleksinio valdymo priemones istaigose, ligoninèse ir mokyklose, atsižvelgiant $i$ architektūrinio ir interjero projektavimo principus".

Keith Alexander [9] nuomone, PŪV, kaip disciplina, apima visus nekilnojamojo turto valdymo aspektus, erdvę, aplinkos kontrolę, sveikatingumą ir sauguma, kitas teikiamas paslaugas.

\section{Autoriụ siūloma pastatụ ūkio valdymo samprata}

Autoriai, remdamiesi atliktų darbu analize [1-9] ir esama patirtimi, siūlo pastatų ūkio valdymą nagrinèti kaip keturias sudètines dalis: erdvès (patalpu), administracinis, techninis ir kitu paslaugụ valdymas. 


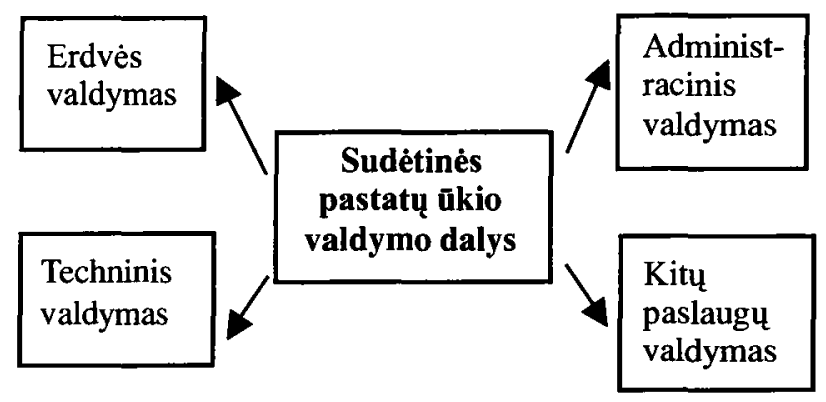

Sudètinès pastatų ūkio valdymo dalys

Facilities management components

\subsection{Erdvès valdymas}

Erdvès valdymas suprantamas kaip paslaugu teikimas, siekiant sudaryti efektyvias organizacijos darbo sąlygas. Erdvès valdymas apima:

- erdvès planavimą ir pritaikymą besikeičiantiems poreikiams;

- ịrenginiụ (valymo, krovimo, sandèliu), irangos (stakliu, programinès), baldu, inventoriaus poreikio analizę ir tiekimą;

- paslaugy teikimą (pastato, patalpu, turto apsauga, budèjimas laukiamajame, telefoninio ryšio, pašto, centrinio archyvo, kurjeriu, dauginimo (kopijavimo aparatai, skeneriai) paslaugos, grindu, langu, stogo valymas, sniego valymas, aplinkos priežiūra, augalu priežiūra pastate, aplinkos apsauga, komandiruočiụ tvarkymas, mašinu stovèjimo vietos organizavimas ir priežiūra, viešojo maitinimo organizavimas, šiukšlių išvežimas ir kitos paslaugos).

\subsection{Administracinis valdymas}

Administracinis valdymas apima:

- pastato naudojimo kontrole (biudžeto tvarkymą ir optimizavimą, teikiamų paslaugų koordinavimą, kontraktiniu isipareigojimu monitoringa, pastato perdavimą ir prièmima, pastato ir automobilių stovéjimo vietos valdymą, dokumentų tvarkyma, pranešimų rengimą ivaizdžio gerinima);

- apskaitą (nuoma, papildomos pajamos, mokesčiai ir pan.);

- sandoriu valdymą (sandorių sudarymas, draudimo sutarčių sudarymas);

- personalo prièmimą i darbą subrangovy kontrolę,

- nuomos ir išperkamosios nuomos valdymą (koncepcijos rengimas ir jos praktinis igyvendinimas).

\subsection{Techninis valdymas}

Techninis valdymas apima:

- sistemy ir irenginiu eksploatavima, inspekcija, remonta, avarini aptarnavimą: duju, vandentiekio, kanalizacijos, šildymo, vandens šildymo, ventiliacijos, elektros, apsaugos nuo žaibo, liftų, transporterių ir sandeliu, automatinių dury ir vartu̧, pastato ir patalpu apsaugos, matavimo ir kontrolès, komunikaciju, kabelinès ir tinklinès, skalbimo ir sausojo valymo, medicinos ir laboratoriju irenginiu, kitų irenginių ir sistemų;

- pastatu konstrukciju ir elementu eksploatavimą, inspekcija, remonta;

- energijos valdymą.

\subsection{Kitų paslaugụ valdymas}

Kitų paslaugu valdymas apima specialias paslaugas pagal užsakovų pageidavimus: kompiuterių ir jų tinklụ, ryšio su internetu, informacinès technologijos diegimą ir valdymą, pastato modeliavimą, konsultavimą energijos taupymo klausimais ir t. $t$.

\section{Autorių atlikto tyrimo tikslai}

Aišku, kad minètos paslaugos ne visos reikalingos konkrečiai organizacijai. Reikiamą paslaugu asortimenta apimti ir kokybę galima nustatyti apklausiant užsakovus, remiantis kitų analogiškų aptarnaujamų organizaciju patirtimi. Paslaugu asortimentas, apimtis ir kokybė priklauso nuo organizacijos poreikiu, jos finansiniu galimybiu ir svarbiausia - nuo ju kainos ir galimybiu padidinti organizacijos veiklos efektyvumą. Tokiu atveju galime spręsti daugiakriterinị uždavinị: suđarę galimus alternatyvių paslaugų variantus ir ivertine pagal tam tikrą kriterijų sistemą išrenkame racionaliausius.

$\mathrm{Ne}$ visada būna aišku, kas ivvairias paslaugas gali teikti racionaliau: vidinè organizacija (t. y. organizacija, teikianti paslaugas savo jègomis), viena ar kelios išorinès organizacijos (kai naudojamasi kitų organizaciju pagalba), bendromis pastangomis. Norint ivertinti alternatyviu organizacijų teikiamu paslaugu efektyvumą, reikia palyginti šiu paslaugų kainą kvadratiniam metrui ar kainą per metus. Apskaičiavus šiuos rodiklius, taip pat ivertinus kitus veiksnius galima parinkti racionalu variantą. Prieš galutinai nusprendžiant, kokias paslaugas gali teikti vidinè organizacija, reikia atsakyti $\mathfrak{i}$ kelis klausimus. $\mathrm{Ar}$ 
vidinè organizacija turi reikiamų technikos, ekonomikos, vadybos žinių, reikiamą irranga, dokumentus, būtinus, norint efektyviai teikti paslaugas? Ar vidinè organizacija rūpinsis personalo nenutrūkstamu mokymu ir geros praktikos perémimu? Ar efektyviai panaudos naujausias technologijas? Dažnai vidinès organizacijos reikiamo lygio specialistų neturi. Vienas iš išorinių organizaciju privalumų yra tas, kad jos, atsižvelgiant i esamą poreikí, gali siūlomų paslaugų asortimentą ir apimti padidinti ar sumažinti.

Autorių tyrimų objektą sudaro pastatų ūkio valdymo procesas, jame dalyvaujančios ir savo tikslus norinčios igyvendinti suinteresuotos grupès bei išorinè mikro- ir makrolygmens aplinka kaip viena visuma.

Straipsnyje siekiama parodyti autoriu sukurtų daugiakriterinès analizès metodų taikymą pastatų ūkio valdymui.

\section{Pastatụ ūkio valdymo kompleksiškumas ir dina- miškumas}

Laikui bẻgant plečiasi pastatų ūkiui teikiamu paslaugu asortimentas, dideja užsakovų keliami reikalavimai pastatui ir jo aplinkai, kaip vientisai sistemai, dideja istatymų reikalavimai sveikatos saugumui, aplinkos apsaugai. Efektyvesnių sąlygų imonès veiklai sudarymas ir darbo sąlygu kokybès gerinimas yra svarbūs veiksniai, didinantys imonių konkurencingumą, kas yra labai svarbu vis didèjančioje konkurencinèje kovoje.

Siekiant sèkmingai spręsti pastatų ūkyje kylančias problemas reikia turèti vadybos, ekonomikos, technikos, psichologijos žiniu ir patyrimo. Tik "hibridinis“ vadybininkas, turintis vadybininko, ekonomisto, techniko ir psichologo kvalifikaciją gali iki galo suprasti kylančias problemas ir jas efektyviai spręsti. Sugebejimas bendrauti ir gauti reikiamą informaciją yra viena iš svarbiausiu vadybininko savybių. Efektyvus grižtamasis ryšys užtikrina, kad organizacija visą laiką žinos vartotoju poreikius, ju patenkinimo lygi ir iš to išplaukiančius naujus pageidavimus. Tai padès užtikrinti, kad reikiamos kokybès ir kainos paslaugos bus teikiamos visa apimtimi pageidaujamu laiku ir norimoje vietoje.

Daugelis pastatų ūkio valdymo organizacijų supranta, kad žmogiškieji ištekliai yra vieni iš svarbiausių veiksniu, lemiančių organizacijos veiklos efektyvumą. Siekiant pritraukti aukštos kvalifikacijos specialistu, jiems mokamas ne tik pakankamai didelis atlyginimas, bet taip pat stengiamasi sudaryti komfortiškas darbo sąlygas.

Organizacijų, teikiančių pastatų ūkio paslaugas, efektyvumas gali būti vertinamas îvairiais požiūriais. Organizacijos tikslus ir uždavinius, veiklą ir jos galutinius rezultatus iš savo atskaitos taško vertina ivairios suinteresuotos grupès: užsakovai, personalas, akcininkai, kreditoriai, tiekejjai, žiniasklaida, savivaldybès ir pan. Šių suinteresuotu grupių vertinimas ne visada sutampa. Tai visiškai suprantama, kadangi skirtingos suinteresuotos grupès organizacijos veiklos efektyvumą vertina pagal labiausiai joms rūpimus veiksnius, todèl gaunamos skirtingos vertinimo kriteriju sistemos. Organizacijos efektyvumas gali būti apibūdinamas kaip geri santykiai organizacijos viduje ir su kitomis suinteresuotomis grupèmis, sugebèjimas gerinti kokybę ir didinti našumą, plèsti teikiamu paslaugų asortimentą ir didinti jų naudingumo ir kainos santyki, mažinti rizika, prisitaikyti prie besikeičiančios išorinès ekonominès, istatymų, politinès, socialinès aplinkos. Pažangiausios organizacijos, siekdamos padidinti savo konkurencingumą ir restruktūrizuodamos savo įmones, pastatų ūkio valdymą laiko sudedamaja šio proceso dalimi. Visos pastatų ūkio valdymo proceso stadijos yra tarpusavyje susijusios. Todèl pastatu ūkio valdymo specialistai turi bendradarbiauti su suinteresuotomis grupèmis per visą pastato gyvavimo procesą. Anksčiau minètos ir kitos priežastys bei tendencijos verčia pastatų ūkio valdymą tapti kompleksiškesniu ir dinamiškesniu organizmu, dèl to didèja jo sudėtingumas ir išlaidos. Tačiau, kita vertus, dažniausiai pagerejja tokie organizacijos veiklos rodikliai, kaip pajamu ir išlaidu santykis, padidèja darbo vietų ir gamybos proceso efektyvumas ir pan.

\section{Projektų daugiakriterine analizè}

Siekiant pastatų ūkio valdymą padaryti kompleksišką ir dinamiška, siūloma taikyti daugiakriterinius projektų vertinimo metodus.

Norint išrinkti efektyviausią projektą (turto valdymo varianta), reikia, sudarius sprendimu prièmimo matrica, atlikti projektų daugiakriterinę analizę. Tai atliekama lyginant nagrinèjamu projektų kriteriju reikšmes ir reikšmingumus, analizuojant koncepcinę informacija. Nagrinėjamą projektą galima apibūdinti tik remiantis daugelio skirtingą prasmę ir dimensijas turinčių kriterijų sistema. Dẻl tokios kriterijų ivairovès yra sunku tie- 
siogiai lyginti projektus. Vienas iš svarbiausių šios problemos sprendimo uždavinių - nustatyti kriteriju reikšmingumus. Tai gali bũti atliekama ekspertiniais metodais [10-14].

Śiuo metu pasaulyje sukurta daug sprendimu prièmimo metodu, taikomu ivairiose žmogaus veiklos srityse. E. K. Zavadskas ir A. Kaklauskas savo darbuose [10-13] išnagrinèjo ir pritaikè projektu daugiakriterinio vertinimo metodus - lošimo teorijos kriterijus (Valdo, Sevidžo, Gurvico, Minimakso), apibendrintus kriterijus (adityviniai, vidutiniškai svertinès priimamo sprendimo sèkmès, multiplikatyviniai, kombinuotieji, naudingumo funkcijos, artumo idealiajam taškui), nuoseklaus optimizavimo metodus (sprendimu suderinamumo (konkordantiškumo), prioritetų nustatymo, nedominuojančiu variantų išrinkimo), sintezès metodus - statyboje. Šie autoriai sukūrẻ ir naujus sprendimy prièmimo metodus: kompleksini kriteriju reikšmingumo nustatymo metoda, atsižvelgiant $\mathfrak{i} j u$ kokybines ir kiekybines charakteristikas; projekty daugiakriterinio kompleksinio proporcingo ivertinimo metodą; daugiakriterini nekilnojamojo turto objektų naudingumo laipsnio ir rinkos vertès nustatymo metoda; pastato gyvavimo proceso daugiakriterinio alternatyvaus projektavimo metodą [10-13].

Šiame straipsnyje daugiakriterinès analizès metodu taikymo galimybès pastatu ūkio valdymo projektu analizei parodomos sprendžiant realu Žirmūnų prekybos centro pastatụ ūkio valdymo projektų racionalaus varianto pasirinkima.

Šiame straipsnyje nagrinèjamų alternatyvų prioritetiškumas ir reikšmingumas skaičiuojami penkiais etapais: sudaroma ivertinta normalizuota sprendimu matrica $D$, apskaičiuojamos $j$ variantą apibüdinančiı minimizuojančiu $S_{-j}$ ir maksimizuojančiı $S_{+j}$ ivertintı normalizuotu rodiklių sumos, nustatomas lyginamų variantụ santykinis reikšmingumas $Q_{j}$, nustatomas lyginamu alternatyvu prioritetiškumas, nustatomas lyginamu variantų naudingumo laipsnis $N_{j}$. Detalus šị etapu aprašymas pateiktas [10-14] literatūros šaltiniuose.

\section{1. Žirmūnų prekybos centro aprašymas}

Žirmūnụ prekybos centras (Žirmūnų 68 a) yra Vilniuje, Žirmūnu mikrorajone. Prekybos centras statytas $1974 \mathrm{~m}$. Jis priklauso nekilnojamojo turto firmai OBER HAUS, būtent ji ir yra šio nekilnojamojo turto savininké ir valdytoja. Prekybos centras yra 2 -jų aukštu, su rūsiu. Bendras naudingasis pastato plotas $-5318 \mathrm{~m}^{2}$. Atlikta ne visa apdaila. Fizinis nusidévejimas nedidelis. Labai patogu privažiuoti, didelè automobiliụ stovéjimo aikštelè. Šiuo metu prekybos centrą išsinuomojusios ivvairios firmos, pvz., „Ritos smuklè“, „Čili picerija“, fotopaslaugu firma „Fuji“ ir kitos. Jos užima apie $3420 \mathrm{~m}^{2}$. Liko $1898 \mathrm{~m}^{2}$ neišnuomoto ploto.

\subsection{Lyginamųụ variantụ aprašymas}

Keičiantis pastatų ūkio valdymo alternatyvoms, keičiasi jụ kaina ir kokybè. Galima nagrinéti daugybę pastatų ūkio valdymo alternatyvul. Kaip pavyzdys šiame straipsnyje nagrinejamos savininko ir nuomininko požiūriu dvi kraštutinès alternatyvos:

- nuoma be paslaugú;

- nuoma su visomis paslaugomis.

Toliau aprašomi šie lyginamieji variantai.

Kai kalbama apie nuomą be paslaugu, turima omeny, kad imamas mokestis tik už naudojimąsi pastato patalpomis. Jokiu paslaugu savininkas ar valdytojas neteikia.

Kai kalbama apie nuomą su visomis paslaugomis, turima omeny, kad imamas mokestis ne tik už naudojimąsi pastato patalpomis, bet ir už tam tikru paslaugu tèikimą. Valdytojas (savininkas) rūpinasi turto apsauga, techninès dalies valdymu, aplinkos priežiūra, patalpų valymu ir t. t.

\subsection{Vertinimo kriterijai}

Nagrinejjamame pavyzdyje, remiantis ekspertų patarimais ir nuomonèmis, geriausiam pastatụ ūkio valdymo variantui nustatyti buvo pasirinkti šie kriterijai: nuomos kaina per mènesi, valdymo išlaidos, nuomininko sugaištas laikas, pelnas nuomojant per mènesĭ, turto apsauga, techninès dalies valdymo kontrolè, aplinkos priežiūra, valymas, sandoriụ valdymas, pastato naudojimo kontrolé, reklama.

Šie kriterijai aprašomi toliau.

Nuomos kaina per mènesi. Remiantis atliktais skaičiavimais, buvo nustatyta $1 \mathrm{~m}^{2}$ kaina: be paslaugu $21 \mathrm{Lt}$, o su visomis paslaugomis - $25 \mathrm{Lt}$.

Valdymo išlaidos buvo nustatytos susumavus apsaugos, patalpu valymo, aplinkos priežiūros, draudimo, pastato naudojimo kontrolés, pastato techninio valdymo ir reklamos išlaidas. 
Nuomininko sugaištas laikas - tai laikas, kuri pastatų ūkio valdymui sugaišta nuomininkas (procentais nuo bendro darbui skirto laiko).

Pelno nuomojant per mènesi kriterijaus reikšmè buvo nustatyta taip: iš pajamų, gautų nuomojant nekilnojamaji turtą, atimamos pastatų ūkio valdymo išlaidos. Šis kriterijus ir jo reikšmė buvo naudojama daugiakriterinès analizès skaičiavimams tik savininko požiūriu.

Turto apsaugos kriterijumi ivertinama turto apsaugos kokybė, t. y. apsauga nuo isilaužimu, vagysčiu ir kt. Kokybė matuojama dešimtbalès sistemos balais.

Technines dalies valdymo kriterijus padeda ivertinti nekilnojamojo turto techninès dalies valdymo kokybę. Techninis valdymas apima tokių sistemų ir irenginių eksploatavimą, inspekciją, remonta, avarinę priežiūrą: dujų, vandentiekio, kanalizacijos, šildymo, vandens šildymo, ventiliacijos, elektros, apsaugos nuo žaibo, liftu, transporterių ir sandèlių, automatinių durų ir vartu, pastato ir patalpu apsaugos, matavimo ir kontrolès, komunikaciju, kabelinès ir tinklinès, skalbimo ir sausojo valymo, medicinos ir laboratoriju irenginiu, kitu irenginių ir sistemų. Kokybè matuojama dešimtbalès sistemos balais.

Aplinkos priežiūros kriterijumi juvertinama pastato aplinkos priežiūros kokybė. I pastato aplinkos priežiūrą ¡eina langu, stogo, sniego valymas, augalų priežiūra, aplinkos apsauga. Kokybė matuojama dešimtbalès sistemos balais.

Pagal valymo kriteriju ivertinama pastato vidaus patalpu ir šiukšliụ išvežimo kokybė. Ji matuojama dešimtbalès sistemos balais.

Sandorių valdymo kriterijus padeda ivertinti nekilnojamojo turto sandorių valdymo kokybe. Sandorių valdymą apima: sandorių sudarymas, draudimo sutarčiu sudarymas ir kt. Kokybè matuojama dešimtbalès sistemos balais.

Pastato naudojimo kontrolès kriterijumi ivvertinamas biudžeto tvarkymas ir optimizavimas, teikiamu paslaugu koordinavimas, sandorio isipareigojimu monitoringas, pastato perdavimas ir prièmimas, pastato ir automobiliu stovejjimo vietos valdymas, dokumentų tvarkymas, pranešimų rengimas, ịvaizdžio gerinimas. Kokybẻ matuojama dešimtbalès sistemos balais.

Reklamos kriterijus padeda ivertinti reklamos visuma. Tai naudinga ne tik nuomininkui, bet ir savininkui. Kokybė matuojama dešimtbalès sistemos balais.
Apklausus 20 pastatų ūkio valdymo srities ekspertụ ir gautus rezultatus apdorojus ekspertiniais metodais buvo apskaičiuotos kokybinių kriterijų (turto apsauga, techninès dalies valdymas, aplinkos priežiūra, valymas, sandorių valdymas, pastato naudojimo kontrolè, reklama) reikšmès. Tiek nuomininko, tiek nuomotojo požiūriu apskaičiuotos kiekybinių ir kokybinių kriteriju reikšmès, išskyrus nuomininko sugaišto laiko ir nuomos pelno kriteriju reikšmes, sutampa. Tai suprantama, kadangi:

- apskaičiuotos kiekybiniu kriteriju (nuomos kaina per mènesị, valdymo išlaidos, nuomininko sugaištas laikas, nuomos pelnas) reikšmès yra objektyvios;

- kokybinių kriteriju reikšmès buvo apskaičiuotos remiantis nepriklausomų pastatu ūkio valdymo srities ekspertų nuomonèmis.

Tačiau nuomininko ir savininko požiūriu apskaičiuoti kriterijų, išsamiai apibūdinančių teikiamas paslaugas, reikšmingumai skiriasi. Tai galima paaiškinti ivvairiomis priežastimis:

- vienam iš ju gali būti reikšmingesni kainos rodikliai, o kitam kokybès rodikliai;

- viena pastaty ūkio valdymo alternatyva gali atrodyti patrauklesnè nuomininkui, o kita savininkui.

\subsection{Pastatų ūkio valdymo projektų efektyvumo dau- giakriterinis vertinimas}

Nagrinejjamu pastatu ūkio valdymo alternatyvu efektyvumą reikia nagrinèti nuomininko ir savininko požiūriais. Todèl, siekiant nustatyti nagrinèjamų pastatı̣ ũkio valdymo alternatyvu efektyvuma, buvo sudarytos dvi sprendimu prièmimu matricos:

- teikiamų paslaugų analizè nuomininko požiūriu (1 lentelè);

- teikiamy paslaugu analizė savininko požiūriu (2 lentelè).

Sudarius šias dvi sprendimų prièmimo matricas (1 ir 2 lent.), atliekama pastatu ūkio valdymo alternatyvu daugiakriterinè analizè. Ši analizè atliekama taikant autorių pasiūlytą projektų daugiakriterinio kompleksinio proporcingo vertinimo metoda [13].

Iš lentelèse pateiktụ duomenų matyti, kad kiekvienas variantas turi tiek teigiamų, tiek neigiamu savybių. Turto apsauga, techninès dalies valdymo kontrolè, aplinkos priežiūra, valymas, sandorių valdymas, pastato naudojimo kontrolè, reklama vertinami balais. Juo didesnis balas, tuo geresnis rodiklis. Pavyzdžiui, iš 1 len- 
1 lentelè. Pradinių skaičiavimų duomenys nuomininko požiūriu

Table 1. Initial calculation data from the point of view of tenants

\begin{tabular}{|c|c|c|c|c|c|c|}
\hline & \multirow[b]{2}{*}{ Nagrinejjamas kriterijus } & \multirow{2}{*}{$*$} & \multirow{2}{*}{$\begin{array}{l}\text { Matavimo } \\
\text { vnt. }\end{array}$} & \multirow{2}{*}{$\begin{array}{l}\text { Kriterijaus } \\
\text { reikšmingumas }\end{array}$} & \multicolumn{2}{|c|}{ Lyginamas nuomos variantas } \\
\hline & & & & & $\begin{array}{l}\text { 1. Nuoma be } \\
\text { paslaugy }\end{array}$ & $\begin{array}{l}\text { 2. Nuoma su visomis } \\
\text { paslaugomis }\end{array}$ \\
\hline 1. & Nuomos kaina per mènesị & - & $\mathrm{Lt} / \mathrm{m}$ & 1 & 21 & 25 \\
\hline 2. & Valdymo išlaidos & - & $\mathrm{Lt} / \mathrm{m}$ & 0,07 & 4000 & 5000 \\
\hline 3. & Nuomininko sugaištas laikas & - & $\%$ & 0,05 & 30 & 5 \\
\hline 4. & Turto apsauga & + & Balai & 0,05 & 6 & 8 \\
\hline 5. & Techn. dalies valdymas & + & Balai & 0,04 & 5 & 8 \\
\hline 6. & Aplinkos priežiūra & + & Balai & 0,04 & 5 & 9 \\
\hline 7. & Valymas & + & Balai & 0,05 & 8 & 10 \\
\hline 8. & Sandoriy valdymas & + & Balai & 0,03 & 6 & 8 \\
\hline 9. & Pastato naudojimo kontrole & + & Balai & 0,03 & 6 & 9 \\
\hline 10. & Reklama & + & Balai & 0,04 & 7 & 9 \\
\hline
\end{tabular}

* Ženklas $+(-)$ rodo, kad didesnè (mažesnè) kriterijaus reikšmè labiau atitinka užsakovo reikalavimus

2 lentelè. Pradinių skaičiavimų duomenys savininko požiūriu

Table 2. Initial calculation data from the point of view of owners

\begin{tabular}{|c|c|c|c|c|c|c|}
\hline & \multirow{2}{*}{ Nagrinejjamas kriterijus } & \multirow{2}{*}{ * } & \multirow{2}{*}{$\begin{array}{l}\text { Matavimo } \\
\text { vnt. }\end{array}$} & \multirow{2}{*}{$\begin{array}{l}\text { Kriterijaus } \\
\text { reikšmingumas }\end{array}$} & \multicolumn{2}{|c|}{ Lyginamas nuomos variantas } \\
\hline & & & & & $\begin{array}{l}\text { 1. Nuoma be } \\
\text { paslaugy }\end{array}$ & $\begin{array}{l}\text { 2. Nuoma su visomis } \\
\text { paslaugomis }\end{array}$ \\
\hline 1. & Nuomos kaina per ménesi & + & $\mathrm{Lt} / \mathrm{m}$ & 1 & 21 & 25 \\
\hline 2. & Valdymo išlaidos & - & $\mathbf{L t}$ & 0,07 & 4000 & 5000 \\
\hline 3. & Nuomos pelnas & + & $\mathrm{Lt}$ & 0,07 & 108000 & 108000 \\
\hline 4. & Turto apsauga & + & Balai & 0,05 & 6 & 8 \\
\hline 5. & Techn. dalies valdymas & + & Balai & 0,04 & 5 & 8 \\
\hline 6. & Aplinkos priežiūra & + & Balai & 0,04 & 5 & 9 \\
\hline 7. & Valymas & + & Balai & 0,05 & 8 & 10 \\
\hline 8. & Sandorių valdymas & + & Balai & 0,03 & 6 & 8 \\
\hline 9. & Pastato naudojimo kontrolè & + & Balai & 0,03 & 6 & 9 \\
\hline 10. & Reklama & + & Balai & 0,04 & 7 & 9 \\
\hline
\end{tabular}

* Ženklas $+(-)$ rodo, kad didesné (mažesnè) kriterijaus reikšmė labiau atitinka užsakovo reikalavimus

telèje pateiktu duomenu matyti, kad variante su visomis paslaugomis teikiamu paslaug $\iota$ (turto apsauga, techninès dalies valdymas, aplinkos priežiūra, valymas, sandoriu valdymas, pastato naudojimo kontrolè ir reklama) kokybè yra geresnè nei nuomos be paslaugu variante.

Juo didesnis reikšmingumas, tuo šis rodiklis yra reikšmingesnis ekspertams, nuomininkui ir nuomotojui bei turès didesni poveiki galutiniam vertinimo rezultatui. Pavyzdžiui, skaičiavimo metu buvo nustatyta, kad valymo reikšmingumas ivertinamas 0,05 balo, o rekla- mos reikšmingumas 0,04 balo, t. $\mathrm{y}$. pirmasis rodiklis reikšmingesnis už antraji $20 \%$.

Daugiakriterinès alternatyvų analizès skaičiavimu rezultatai nuomininko požiūriu pateikiami 3 lentelèje. Iš gautu rezultaty matome, kad nuomos su visomis paslaugomis variantas yra geresnis nuomininkui, o nuomos be paslaugu variantas jam yra mažiau naudingas $9 \%$.

Daugiakriterinès alternatyvų analizès skaičiavimų rezultatai savininko požiūriu pateikiami 4 lentelèje. Iš gautụ rezultatụ matome, kad nuomos su visomis paslaugo- 
3 lentelè. Daugiakriteriné alternatyvų analizé nuomininko požiūriu

Table 3. Multiple criteria alternatives analysis from the point of view tenants

\begin{tabular}{|c|c|c|c|c|c|c|}
\hline & \multirow{2}{*}{ Nagrinèjamas kriterijus } & \multirow{2}{*}{$*$} & \multirow{2}{*}{$\begin{array}{l}\text { Matavimo } \\
\text { vnt. }\end{array}$} & \multirow{2}{*}{$\begin{array}{l}\text { Kriterijaus } \\
\text { reikšmingumas }\end{array}$} & \multicolumn{2}{|c|}{ Lyginamas nuomos variantas } \\
\hline & & & & & $\begin{array}{l}\text { 1. Nuoma be } \\
\text { paslaugu }\end{array}$ & $\begin{array}{c}\text { 2. Nuoma su visomis } \\
\text { paslaugomis }\end{array}$ \\
\hline 1. & Nuomos kaina per mėnesi & - & $\mathrm{Lt} / \mathrm{m}$ & 1 & 0,45652 & 0,54347 \\
\hline 2. & Valdymo išlaidos & - & $\mathrm{Lt} / \mathrm{m}$ & 0,07 & 0,06481 & 0,00519 \\
\hline 3. & Nuomininko sugaištas laikas & - & $\%$ & 0,06 & 0,05142 & 0,00857 \\
\hline 4. & Turto apsauga & + & balai & 0,05 & $0, \overline{02142}$ & 0,02857 \\
\hline 5. & Techn. dalies valdymas & + & balai & 0,04 & 0,01538 & 0,02461 \\
\hline 6. & Aplinkos priežiūra & + & balai & 0,04 & 0,01428 & 0,02571 \\
\hline 7. & \begin{tabular}{|l|} 
Valymas \\
\end{tabular} & + & balai & 0,05 & 0,02222 & 0,02778 \\
\hline 8. & Sandorių valdymas & + & balai & 0,03 & 0,01285 & 0,01714 \\
\hline 9. & Pastato naudojimo kontrolè & + & balai & 0,03 & 0,01200 & 0,01800 \\
\hline 10. & Reklama & + & balai & 0,04 & 0,01750 & 0,02250 \\
\hline 11. & \multicolumn{4}{|c|}{ Maksimizuojančių normalizuotų ivertinimų rodiklių suma $S_{+j}$} & 0,11567 & 0,16432 \\
\hline 12. & \multicolumn{4}{|c|}{ Minimizuojančių normalizuotụ ịvertinimo rodiklių suma $S_{-j}$} & 0,57276 & 0,55723 \\
\hline 13. & \multicolumn{4}{|c|}{ Reikšmingumas $Q_{j}$} & 0,67291 & 0,73708 \\
\hline 14. & \multicolumn{4}{|l|}{ Prioritetas } & 2 & 1 \\
\hline 15. & \multicolumn{4}{|l|}{ Naudingumo laipsnis $N_{i}$} & $91 \%$ & $100 \%$ \\
\hline
\end{tabular}

* Ženklas $+(-)$ rodo, kad didesnè (mažesnè) kriterijaus reikšmė labiau atitinka užsakovo reikalavimus

4 lentelè. Daugiakriterinè alternatyvı̨ analizè savininko požiūriu

Table 4. Multiple criteria alternatives analysis from the point of view of owners

\begin{tabular}{|c|c|c|c|c|c|c|}
\hline & \multirow{2}{*}{ Nagrinejamas kriterijus } & \multirow{2}{*}{ * } & \multirow{2}{*}{$\begin{array}{l}\text { Matavimo } \\
\text { vnt. }\end{array}$} & \multirow{2}{*}{$\begin{array}{c}\text { Kriterijaus } \\
\text { reikšmingumas }\end{array}$} & \multicolumn{2}{|c|}{ Lyginamas nuomos variantas } \\
\hline & & & & & $\begin{array}{l}\text { 1. Nuoma be } \\
\text { paslaugy }\end{array}$ & $\begin{array}{l}\text { 2. Nuoma su visomis } \\
\text { paslaugomis }\end{array}$ \\
\hline 1. & Nuomos kaina per mènesi & + & $\mathrm{Lt} / \mathrm{m}$ & 1 & 0,45652 & 0,54348 \\
\hline 2. & Valdymo išlaidos & - & Lt. & 0,07 & 0,00966 & 0,06034 \\
\hline 3. & Nuomos pelnas & + & Lt. & 0,06 & 0,03000 & 0,03000 \\
\hline 4. & Turto apsauga & + & Balai & 0,05 & 0,02143 & 0,02857 \\
\hline 5. & Techn. dalies valdymas & + & Balai & 0,04 & 0,01538 & 0,02462 \\
\hline 6. & Aplinkos priežiūra & + & Balai & 0,04 & 0,01429 & 0,02571 \\
\hline 7. & Valymas & + & Balai & 0,05 & 0,02222 & 0,02778 \\
\hline 8. & Sandorių valdymas & + & Balai & 0,03 & 0,01286 & 0,01714 \\
\hline 9. & Pastato naudojimo kontrolè & + & Balai & 0,03 & 0,01200 & 0,01800 \\
\hline 10. & Reklama & + & Balai & 0,04 & 0,01750 & 0,02250 \\
\hline 11. & \multicolumn{4}{|c|}{ Maksimizuojančių normalizuotų įvertinimų rodiklių suma $S_{+j}$} & 0,60220 & 0,73780 \\
\hline 12. & \multicolumn{4}{|c|}{ Minimizuojančių normalizuotụ ịvertinimo rodikliụ suma $S_{-j}$} & 0,00966 & 0,06034 \\
\hline 13. & \multicolumn{4}{|c|}{ Reikšmingumas $Q_{j}$} & 0,66254 & 0,74746 \\
\hline 14. & \multicolumn{4}{|l|}{ Prioritetas } & 2 & 1 \\
\hline 15. & \multicolumn{4}{|l|}{ Naudingumo laipsnis $N_{j}$} & $89 \%$ & $100 \%$ \\
\hline
\end{tabular}

* Ženklas $+(-)$ rodo, kad didesnè (mažesnè) kriterijaus reikšmė labiau atitinka užsakovo reikalavimus 
mis variantas yra geresnis nuomininkui, o nuomos be paslaugų variantas jam yra mažiau naudingas $11 \%$.

Lyginamų variantų naudingumo laipsnis išreiškia nuomininko ir savininko tikslu pasiekimo lygi. Juo daugiau ir reikšmingesnių pasiekta tikslụ, tuo didesnis varianto naudingumo laipsnis. Pateikto pavyzdžio atveju lyginamojo varianto nuomos be paslaugu kokybè yra blogesnè nei varianto nuomos su visomis paslaugomis.

\section{Išvados}

Pateikta autorių siūloma pastatụ ūkio valdymo samprata dabartinèmis Lietuvos ekonominèmis salygomis.

Straipsnyje pateiktas autorių sukurtų daugiakriterinès analizès metodų taikymas pastatų ūkio valdymui siekiant dinamiškumo ir kompleksiškumo. Kaip pavyzdys buvo atlikta daugiakriterinė pastatı ùkio valdymo variantų analizè. Jos metu iš dviejų Žirmūnų prekybos centro pastato $\left(5318 \mathrm{~m}^{2}\right)$ kraštutinių valdymo variantu - nuoma be paslaugu arba nuoma su visomis paslaugomis - buvo ieškoma geriausio varianto. Atlikus skaičiavimus tiek nuomininko, tiek savininko požiūriu (3 ir 4 lentelès), paaiškejjo, kad abiem atvejais nuomos be paslaugu naudingumo laipsnis $N_{j}$ (t. y. $N_{j 1}=91 \%$ ir $N_{j 2}=89 \%$ ) yra $9 \%$ ir $11 \%$ mažesnis už nuomos su visomis paslaugomis naudingumo laipsni, kuris abiem atvejais yra $N_{j}=100 \%$. Pasiūlytus pastatu ūkio valdymo diaugiakriterinius analizès metodus galima taikyti ir kitiems pastatụ ūkio valdymo uždaviniams spręsti.

\section{Literatūra}

1. P. Zechel. Facility-Management in der Praxis: Herausforderung in Gegenwart und Zukunft. RenningenMalmsheim: Expert-Verlag, 1997. 167 p.

2. H. Tempelmans Plat. A Housing Cost Allocation Schemes for Facilities Management, International Building Economics. Hong Kong, 1995.

3. Peter Barrett. Facilities Management. Research Directions. RICS Books, London. 1993. 250 p.

4. Peter Barrett. Facilities Management: towards best practice. December. 1994. 263 p.

5. Wes McGregor and Danny Shiem-Shim Then. Facilities management and the business of space. London, 1999. 248 p.

6. D. S. S. Then. Facilities management-the relationship between business and property // Proceedings of EuroFM/ OFMA Conference on Facility Management European Opportunities. Brussels, 1994, p. 259.

7. D. S. S. Then. People, property and technology-manag- ing the interface // Facilities journal, Vol 2, No 1, 1994, p. 6-8.

8. Franklin Becker. Workplace. New York, 1981.

9. Keith Alexander. Facilities Management. Theory and Practice. $1997.173 \mathrm{p}$.

10. E. K. Zavadskas, A. Kaklauskas. Pastaty sistemotechninis vertinimas. Vilnius: Technika, 1996. 280 p.

11. E. Zavadskas, O. Kapliński, A. Kaklauskas, J. Brzezinski. Expert systems in construction industry. Trends, Potential and Applications. Vilnius: Technika, 1995. $179 \mathrm{p}$.

12. E. Zavadskas, F. Peldschus, A. Kaklauskas. Multiple criteria evaluation of projects in construction. Vilnius: Technika, 1994. 227 p.

13. E. K. Zavadskas, L. Simanauskas, A. Kaklauskas. Sprendimu paramos sistemos statyboje. Vilnius: Technika, 1998. 235 p.

14. E. K. Zavadskas, E. Bejder, A. Kaklauskas. Raising the efficiency of the building lifetime with special emphasis on maintenance // Facilities journal, Vol 16, No 11, 1998, p. $334-340$.

Iteikta 20010320

\section{FACILITIES MANAGEMENT MULTIPLE CRITERIA ANALYSIS}

\section{E. K. Zavadskas, A. Kaklauskas, N. Lepkova, J. Zalatorius}

Su m m a r y

There are many definitions of facilities management. Wes McGregor and Danny Shiem-Shim Then describe facilities management (FM) as ,the infrastructure that supports the people in the organization in their endeavours to achieve business goals". In other words, facilities are the tools which people in the business have at their disposal to carry out their tasks.

The Library of Congress (USA) provides an initial definition that is often quoted to explain the breadth of the field of facilities management: "The practice of coordinating the physical workplace with the people and work of the organization; integrates the principles of business administration, architecture and the behavioural and engineering sciences".

One of the most exact definitions of Facility Management used by F. Becker is: "Facility Management is a term which encompass the activities in planning, designing and managing complex facilities such as offices, hospitals and schools, differ from architecture and interior design".

The scope of the discipline covers all aspects of property, space, environmental control, health and safety, and support services, and requires that appropriate control point are established in the organization.

The article presents an example of multiple criteria analysis of commerce centre in Vilnius. Initial data are given in Tables 1 and 2. A comparison of premises lease alternatives is carried out: from the tenant point of view and from that of the owner. The result - the best variant for tenants and owner is to rent the premises with all services. 
Edmundas Kazimieras ZAVADSKAS. Doctor Habil, Professor. Rector of Vilnius Gediminas Technical University. Member of Lithuanian Academy of Sciences. Member of Ukrainian Academy of Technological Cybernetics. Vilnius Gediminas Technical University, Sauletekio al. 11, LT-2040 Vilnius, Lithuania. Rector@adm.vtu.lt

In $1973 \mathrm{Dr}$ degree in building structures. Professor at the Dept of Building Technology and Management. In 1987 Dr Habil degree (problems of building technology and management). Research visits to Moscow Civil Engineering Institute, Leipzig and Aachen Technical University. He maintains close academic links with the universities of Aalborg (Denmark), Salford and Glamorgan (Great Britain), Poznan University of Technology (Poland), Leipzig Higher School of Technology, Economics and Culture (Germany) and Aachen Technical University (Germany). Member of international organizations. Member of steering and programme committees of many international conferences. Member of editorial boards of some research journals. Author of monographs in Lithuanian, English, German and Russian. Research interests: building technology and management, decision-making theory, automation in design, expert systems.
Artūras KAKLAUSKAS. Doctor Habil, Professor. Dept of Construction Economics and Property Management. Vilnius Gediminas Technical University, Saulètekio al. 11, LT-2040 Vilnius, Lithuania. E-mail: property@st.vtu.lt

A graduate of Vilnius Civil Engineering Institute (since 1990 Vilnius Technical University) (1984, civil engineer). $\mathrm{PhD}$ (1990). Research visits to Aalborg University (Denmark, 1991), University of Glamorgan (UK, 1993/1995). Author and coauthor of 4 monographs and more than 50 papers. Research interests: multiple criteria decision-making, expert systems, total quality management, computer-aided design.

Natalija LEPKOVA. PhD student. Dept of Construction Economics and Property Management. Vilnius Gediminas Technical University (VGTU), Saulètekio al. 11, LT-2040 Vilnius, Lithuania. E-mail: Natalija.Lepkova@st.vtu.lt

A graduate of VGTU. MSc (1998). Research visits to Helsinki Polytechnic (Finland, 1999), Technical University of Poznan (Poland, 1999), Aalborg University (Denmark, 2000). Research interests: facilities management.

Juozas ZALATORIUS. Doctor. Dept of Construction Economics and Property Management. Vilnius Gediminas Technical University, Saulètekio al. 11, LT-2040 Vilnius, Lithuania.

A graduate of Vilnius University (1984). PhD (1982). Author of 19 papers. Research interests: e-business systems and real estate management. 